\title{
22. SOURCE AND MATURITY OF ORGANIC MATTER IN GLACIAL AND CRETACEOUS SEDIMENTS FROM PRYDZ BAY, ANTARCTICA, ODP HOLES 739C AND 741A ${ }^{1}$
}

\author{
Thomas J. McDonald, ${ }^{2}$ Mahlon C. Kennicutt II, ${ }^{2}$ Janina K. Rafalska, ${ }^{2,3}$ and Richard G. Fox ${ }^{4,5}$
}

\begin{abstract}
Organic matter in Miocene glacial sediments in Hole $739 \mathrm{C}$ on the Antarctic Shelf represents erosional recycled continental material. Various indications of maturity in bulk organic matter, kerogens, and extracts imply that an exposed section of mature organic carbon-rich material was present during the Miocene. Based on biomarker, $n$-alkane, and kerogen analysis, a massive diamictite of early Eocene/Oligocene age at Hole $739 \mathrm{C}$ contains immature organic matter. Visual and pyrolysis analyses of the kerogens suggest a predominance of terrestrial organic matter in all samples from Hole 739C. A reversal of thermal maturities, i.e., more-mature overlying less-mature sections, may be related to redeposition generated from glacial erosion.

Siliciclastic fluviatile sediments of Lower Cretaceous age from Hole 741A were analyzed. The organic matter from this hole contains immature aliphatic and aromatic biomarkers as well as a suite of odd carbon number-dominated $n$ alkanes. Visual examination and pyrolysis analysis of the kerogen suggests that predominantly immature terrestrial organic matter is present at Hole 741A. The similarities between Hole 739C Unit V and Hole 741A suggest that the source of the organic matter in the glacial sediments in Unit V at Hole $739 \mathrm{C}$ could be Cretaceous in age and similar to sediments sampled at Hole 741A in Prydz Bay.
\end{abstract}

\section{INTRODUCTION}

The molecular and bulk characteristics of organic matter can be useful in defining paleodepositional environments, determining original biological inputs, and inferring sediment's thermal history (e.g., Barker, 1979). For example, long-chain $n$-alkanes ( $>21$ carbon atoms) with an odd over even carbon number predominance (Eglinton et al., 1962) and abundant $C_{29}$ steranes are believed to be primarily associated with terrestrial or land-derived inputs (Huang and Meinschein, 1976). A second example is that the presence of a complex mixture of cyclic, branched, and normal alkanes and polynuclear aromatic hydrocarbons $(\mathrm{PAH})$ indicates a petroleum or mature organic matter origin for hydrocarbons (Farrington and Meyers, 1975). Biologically derived hydrocarbons are relatively simple mixtures containing only a few structurally specific alkanes, alkenes, and aromatics derived from the remains of plankton, bacteria, and/or terrestrial debris (Farrington et al., 1973).

Ratios between biological precursors and their transformed products, such as the $22 \mathrm{~S} / 22 \mathrm{R}$ isomers of the extended hopanes and ratios between methyl phenanthrene isomers, reflect the thermal history of a sedimentary sequence (see Philp, 1985 for an overview). The chemical and optical characteristics of kerogen also define organic matter sources and thermal history (i.e., thermal indexes, van Krevelen diagrams, etc.; Tissot and Welte, 1978). In this report the molecular, bulk, and visual characteristics of sedimentary organic matter are used to understand the source and maturity of sediments from Ocean Drilling Program (ODP) Prydz Bay, Holes 739C and 741A.

\footnotetext{
${ }^{1}$ Barron, J., Larsen, B., et al., 1991. Proc. ODP, Sci. Results, 119: College Station, TX (Ocean Drilling Program).

${ }^{2}$ Geochemical and Environmental Research Group, College of Geosciences, Texas A\&M University. 833 Graham Road, College Station, TX 77845, U.S.A.

3 Present address: Conoco, Inc., 1000 South Pine, RW 6457, P.O. Box 1267 , Ponca City, OK 74603, U.S.A.

4 PTI Environmental Services, 15375 S.E. 30th Place, Suite 250, Bellevue, WA 98007 , U.S.A.

5 Present address: Great Lakes National Program Office, U.S.E.P.A., 230 South Dearborn St., Chicago, IL 60604, U.S.A.
}

\section{GEOLOGIC SETTING}

Prydz Bay lies oceanward of a graben occupied by the Lambert Glacier and Amery Ice Shelf in east Antarctica. The Lambert Glacier drains a large part of the east Antarctica ice sheet including the subglacial Gamburstev Mountains. The glacier follows the line of the Lambert Graben, which extends $700 \mathrm{~km}$ inland and is of Permian or Early Cretaceous age. The present configuration of the ice drainage basin is thought to have remained relatively constant during the Cenozoic; therefore, Prydz Bay sediments should reflect all stages of Antarctic glaciation and preglacial continental climate (Barron, Larsen, et al., 1989). Hole 739C lies in central Prydz Bay and is approximately $30 \mathrm{~km}$ from the shelf edge, $200 \mathrm{~km}$ from land, and $140 \mathrm{~km}$ from the Amery Ice Shelf. Hole 741A was drilled in eastern Prydz Bay and is approximately $50 \mathrm{~km}$ southeast of Hole $739 \mathrm{C}$.

\section{METHODS}

\section{Extractable Organic Matter}

Freeze-dried samples were ground, weighed into a thimble, and soxhlet extracted for $12 \mathrm{hr}$ with dichloromethane. Copper turnings were added to the boiling flask to remove elemental sulfur. Extractable organic matter (EOM) concentration was determined gravimetrically by weighting an aliquot of the extract on a Cahn Electro-balance. The extract was evaporated to 500 $\mu \mathrm{L}$ with purified nitrogen and internal standards $\left(\mathrm{d}_{10}\right.$-phenanthrene, $\mathrm{d}_{12}$-chrysene, and $\mathrm{d}_{42}$-pristane) were added. Internal standards are used to correct for losses during sample preparation and analysis. The extracts were separated into aliphatic and aromatic fractions using a high performance liquid chromatographic method modified from Killops and Readman (1985). Aliphatic and aromatic hydrocarbons were analyzed by gas chromatography with flame ionization (GC/FID) and mass spectrometric detection (GC/MS), respectively.

Aliphatic hydrocarbons were separated on a $30 \mathrm{~m} \times 0.32 \mathrm{~mm}$ I.D. (0.32- $\mu \mathrm{m}$ film thickness) fused silica capillary column coated with 5\% phenyl methyl silicone (DB-5). Aromatic hydrocarbons were separated on a fused silica column coated with $50 \%$ phenyl methyl silicone (DB-17). The carbon preference index (CPI) is defined as the ratio of the concentrations of odd-numbered nor- 
mal alkanes with 23 to 31 carbons to the even-numbered normal alkanes with 24 to 32 carbons. The aliphatic fractions were purified by adduction with $5-\AA$ molecular sieve beads before GC/ MS analysis.

Mass spectrometric analysis was performed with a HewlettPackard 5885 GC/MS system linked to an HP 1000 computer for data storage and processing. The GC/MS was operated in the electron impact mode at $70 \mathrm{eV}$. The injection port, interface, and source temperatures were set at $300^{\circ}, 280^{\circ}$, and $250^{\circ} \mathrm{C}$, respectively. Operating in a selected ion monitoring mode, the aliphatic fractions were analyzed for triterpanes $(\mathrm{m} / \mathrm{z}=191)$, steranes $(\mathrm{m} / \mathrm{z}=217)$, and demethylated triterpanes $(\mathrm{m} / \mathrm{z}=$ 177). Aromatic fractions were analyzed for naphthalenes $(\mathrm{m} / \mathrm{z}$ $=128,142,156,170$, and 184), phenanthrenes $(\mathrm{m} / \mathrm{z}=178$, $192,206$, and 220$)$, monoaromatized steranes $(\mathrm{m} / \mathrm{z}=253)$, and triaromatized steranes $(\mathrm{m} / \mathrm{z}=231)$.

\section{Bulk Parameters}

Total organic carbon (TOC) was determined on an aliquot of ground sediment that was passed through a $60-\mu \mathrm{m}$ mesh sieve. Approximately $0.2 \mathrm{~g}$ of sediment was treated with concentrated hydrochloric acid to remove inorganic carbonate minerals. The residue was analyzed with a LECO EC-12 carbon analyzer. RockEval pyrolysis (Peters, 1986) analysis was conducted on $0.1 \mathrm{~g}$ of sediment. Vitrinite reflectance $\left(R_{o}\right)$ was measured by reflected light microscopy and thermal alteration indexes (TAI) were determined by transmitted light for isolated kerogen samples.

Extracts and acid-treated sediments were combusted to carbon dioxide for stable carbon isotopic analysis in precombusted pyrex tubes containing cupric oxide $(2 \mathrm{~g})$. The carbon dioxide was analyzed with a triple-collector Finnigan MAT-251 Isotope Ratio Mass Spectrometer. Measurements were normalized to Norite $\left(\delta^{13} \mathrm{C}=-24.8 \%\right.$ ) and NBS-22 $\left(\delta^{13} \mathrm{C}=-29.8 \%\right)$. All values are reported relative to the Peedee Belemnite standard (precision $\pm 0.2 \%$ )

\section{RESULTS AND DISCUSSION}

\section{Hole 739C_-Outer Prydz Bay}

Hole 739 C was drilled on the outer part of Prydz Bay in $412 \mathrm{~m}$ of water. The $486.8-\mathrm{m}$ sequence of glacial sediments ranges in age from late Eocene/early Oligocene to Quaternary and is subdivided into five lithologic units (Barron, Larsen, et. al., 1989). TOC ranges from $0.20 \%$ to $2.97 \%(\mathrm{n}=68)$ with the majority of the samples above $0.5 \%$ (Barron, Larsen, et al., 1989). The highest values, greater than $1.2 \%$, are located in Unit II, 24 to $174 \mathrm{~m}$ below seafloor (mbsf). TOC concentrations in Unit V, 315 to 486 mbsf, vary from $0.56 \%$ to $0.73 \%$. Unit II is late Miocene in age and is dominated by a massive diamictite containing $10 \%-20 \%$ gravel and with up to $10 \%$ diatoms (Hambrey et al., this volume). Unit V is of middle Eocene/Oligocene age, and consists of a massive diamictite with minor calcareous cement (Hambrey et al., this volume). Samples from five depth intervals in Units II and V containing high amounts of organic carbon were selected for detailed organic geochemical analysis.

\section{Bulk Parameters}

The abundance of organic matter, TOC and EOM content, and visual and chemical characterization of kerogens from Hole 739C are summarized in Tables 1 and 2. EOM concentrations and organic carbon content in samples analyzed from Unit II range from 140.2 to $215.4 \mathrm{ppm}$ and $1.13 \%$ to $1.56 \%$, respectively. $\mathrm{T}_{\max }$ values of $451^{\circ} \mathrm{C}$, hydrogen indexes (HI) of 57 to 66 , oxygen indexes (OI) of 27 to 36 , production indexes (PI) less than $0.20, S_{1}$ values less than 0.2 , and $S_{2}$ values less than 1.0 suggest that the kerogen is terrestrial in origin and immature (Tissot and Welte, 1978; Peters, 1986). Visual examination of the kerogen classifies the majority of the kerogen $(60 \%$ to $70 \%)$ in Unit II as a mixture of oxidized vitrinite and inertinite. Vitrinite is principally derived from higher land plants and represents the humified remains of lignin and cellulose. Inertinite macerals, also termed charcoal or semicharcoal, suggest a recycled, or secondary, source from the erosion of uplifted sedimentary rocks that were previously deeply buried in the subsurface (Dow, 1977). Amorphous kerogen, which may be derived from the selective preservation of resistant biomacromolecules (Tegelaar et al., 1989) or the precipitation of dissolved or colloidal organic matter such as humic acids (Tissot and Welte, 1978), accounts for $20 \%$ to $30 \%$ of the total kerogen. The red-brown color and lack of fluorescence of the amorphous kerogen in Unit II suggests an allochthonous origin. A van Krevelen diagram shows the kerogens to be highly altered Type III material (Fig. 1). Stable carbon isotope composition of the kerogens ranges from $-22.8 \%$ to $-23.3 \%$ and $\mathrm{EOM}$ values range from $-24.6 \%$ to $-25.2 \%$. Genetically related oils EOM and kerogen have $\delta^{13} \mathrm{C}$ ratio where the kerogen is $0.5 \% 0-1.5 \%$ heavier than the EOM (Schoell, 1982). The difference between kerogen and EOM $\delta^{13} \mathrm{C}$ values of $-1.3 \%_{0}$ to $-2.2 \%_{0}$ is suggestive of genetically related kerogen and EOM.

The EOM and TOC concentrations in two samples from Unit $V$ are 99.7 and $135.2 \mathrm{ppm}$ and $0.51 \%$ and $0.85 \%$, respectively. HI values of 82 and 137, OI values of 68 and 92, PI values less than $0.2, S_{1}$ values less than 0.2 , and $S_{2}$ values less than 1.0 suggest that the organic matter is primarily terrestrial in origin (Tissot and Welte, 1978). The $\mathrm{T}_{\max }$ values $435^{\circ}$ and $445^{\circ} \mathrm{C}$ as well as the $R_{o}$ values of 0.46 and 0.56 , are lower than those in Unit II, suggesting that the kerogen is slightly less mature. Visual examination of the kerogen classifies the organic matter as predominantly vitrinite and amorphous ( $70 \%$ to $75 \%)$. Unit V contains less inertinite and more exinite than Unit II. Kerogen characteristics are consistent with a depositional environment dominated by reworked organic matter of a continental origin. The exinite macerals may be contemporaneous with the originally deposited sediments rather than with the recycled sediments. A van Krevelen diagram characterizes the kerogens as highly altered Type III (Fig. 1). The stable carbon isotope composition of the kerogens $(-23.5 \%$ and $-23.4 \% 0)$ and the EOM $(-26.6 \%$ and $-26.9 \%$ ) exclude the possibility of genetic relationship between EOM and kerogen. The $\delta^{13} \mathrm{C}$ differences between the kerogen and the associated EOM are $-3.1 \%$ and $-3.5 \%$, much higher than those observed in Unit II. The relative enrichment of the EOM in ${ }^{12} \mathrm{C}$ may be attributed to contamination by mature oil, possibly implying paleoseepage.

\section{Extractable Organic Matter}

Hydrocarbon data and gas chromatograms for samples from Unit II are summarized in Tables 3-5 and displayed in Figure 2, respectively. The $n$-alkanes in Unit II are a homologous series with 11 to 32 carbons that is typical of petroleum and not of immature sediments. CPI values average 1.7 , the dominant $n$-alkane is $n-C_{18}$ or $n-C_{19}$, and pristane to phytane ratios vary from 3.8 to 4.3 . The indications of maturity are difficult to reconcile with the young geologic age of this section, suggesting that the hydrocarbons are non-indigenous. The $n$-alkanes and isoprenoids may be the result of erosion of exposed mature continental sediments, an infusion of migrated oil from deep in the section, and/or paleoseepage deposited with the sediment.

Selected GC/MS data are presented in Tables 4 and 5. $\mathrm{T}_{\mathrm{s}} / \mathrm{T}_{\mathrm{m}}$ values vary from 0.13 to 0.14 and the hopane/moretane ratios vary from 2.70 to 3.26 and 2.38 to 3.05 for the $C_{29}$ and $C_{30}$ compounds, respectively. The $22 \mathrm{~S} /(22 \mathrm{~S}+22 \mathrm{R})$ ratio of the $\mathrm{C}_{31}$ hopanes varies from 0.62 to 0.64 and the $20 \mathrm{~S} /(20 \mathrm{~S}+20 \mathrm{R})$ ratio for the $\mathrm{C}_{29}$ steranes average 0.43 . The abundance of $17 \alpha(\mathrm{H}), 21 \beta(\mathrm{H})$ hopanes, elevated isomeric ratios of the steranes, and ratios of the 
Table 1. Rock-Eval data for selected samples.

\begin{tabular}{lcccccccc}
\hline $\begin{array}{l}\text { Core-Section, } \\
\text { Interval }(\mathrm{cm})\end{array}$ & $\begin{array}{c}\text { Depth } \\
(\mathrm{mbs})\end{array}$ & $\begin{array}{c}\mathrm{TOC} \\
(\%)\end{array}$ & $\begin{array}{c}\mathrm{S}_{1} \\
(\mathrm{mg} \mathrm{HC} / \mathrm{g})\end{array}$ & $\begin{array}{c}\mathrm{S}_{2} \\
(\mathrm{mg} \mathrm{HC} / \mathrm{g})\end{array}$ & $\begin{array}{c}\mathrm{S}_{3} \\
\left(\mathrm{mg} \mathrm{CO}_{2} / \mathrm{g}\right)\end{array}$ & $\begin{array}{r}\mathrm{T}_{\max } \\
\left({ }^{\circ} \mathrm{C}\right)\end{array}$ & $\begin{array}{c}\mathrm{HI} \\
(\mathrm{mg} \mathrm{HC} / \mathrm{g})\end{array}$ & $\begin{array}{c}\mathrm{OI} \\
\left(\mathrm{mg} \mathrm{CO}_{2} / \mathrm{g}\right)\end{array}$ \\
\hline \hline
\end{tabular}

\section{$\underline{119-739 C}$}

16R-3, 28-34

2OR-2, $31-37$

23R-2, 44-51

47R-1, 71-78

60R-1, 85-92

$\begin{array}{llllll}133.6 & 1.50 & 0.13 & 0.93 & 0.54 & 451 \\ 151.5 & 1.13 & 0.18 & 0.75 & 0.35 & 451 \\ 165.9 & 1.56 & 0.15 & 0.89 & 0.42 & 452 \\ 386.6 & 0.85 & 0.11 & 0.70 & 0.58 & 435 \\ 473.7 & 0.51 & 0.13 & 0.70 & 0.47 & 445\end{array}$

$\begin{array}{rl}62 & 36 \\ 66 & 31 \\ 57 & 27 \\ 82 & 68 \\ 137 & 92\end{array}$

0.12

0.19

0.14

0.14

82
137

0.16

\section{9-741A}

$5 \mathrm{R}-1,39-45$
$8 \mathrm{R}-1,13-18$

13R-3, 15-20

14R-1, $40-46$

$\begin{array}{rll}33.8 & 4.16 & 0.20 \\ 62.6 & 3.21 & 0.12 \\ 113.9 & 4.50 & 0.18 \\ 120.9 & 4.11 & 0.10\end{array}$

2.88
1.15
3.07
0.71

3.13

2.95

2.99

430
430
428
435

69
36
68
17

75
92
66
57

0.06

0.09

$2.36 \quad 435$

0.12

Table 2. Bulk parameters for selected samples from Leg 119, Holes 739C and 741A.

\begin{tabular}{lllcccccc}
\hline $\begin{array}{l}\text { Core-Section, } \\
\text { Interval }(\mathrm{cm})\end{array}$ & $\begin{array}{c}\text { Depth } \\
\text { (mbs) }\end{array}$ & $\begin{array}{c}\text { EOM } \\
\text { (ug/g) }\end{array}$ & $\begin{array}{c}\text { TOC } \\
\%\end{array}$ & $\begin{array}{c}\delta^{13} \mathrm{C} \\
\text { of kerogen } \\
(\%)\end{array}$ & $\begin{array}{c}\delta^{13} \mathrm{C} \\
\text { of EOM } \\
(\%)\end{array}$ & $\begin{array}{c}\text { Interpreted } \\
\mathrm{R}_{0}\end{array}$ & $\begin{array}{c}\text { TAl } \\
\text { Amorphous }\end{array}$ & $\begin{array}{c}\text { Exinite } \\
\text { Vitrinite }\end{array}$ \\
\hline \hline
\end{tabular}

\section{$119-739 \mathrm{C}$}

\begin{tabular}{|c|c|c|c|c|c|c|c|c|c|c|c|c|}
\hline $16 \mathrm{R}-3,28-34$ & 133.6 & 205.2 & 1.50 & -23.3 & -24.6 & 0.69 & $a_{2}$ & 20 & 5 & 50 & 20 & 5 \\
\hline $20 R-2,31-37$ & 151.5 & 140.2 & 1.13 & -23.0 & -25.2 & 0.73 & $a_{3}$ & 30 & 5 & 35 & 25 & 5 \\
\hline $23 R-2,44-51$ & 165.9 & 215.4 & 1.56 & -22.8 & -24.6 & 0.71 & $a_{3}$ & 30 & $\mathrm{tr}$ & 40 & 25 & 5 \\
\hline $47 \mathrm{R}-1,71-78$ & 386.6 & 99.7 & 0.85 & -23.5 & -26.6 & 0.46 & $a_{3}$ & 35 & 10 & 35 & 15 & 5 \\
\hline $60 \mathrm{R}-1,85-92$ & 473.7 & 135.2 & 0.50 & -23.4 & -26.9 & 0.56 & $a_{3}$ & 25 & 10 & 50 & 10 & 5 \\
\hline \multicolumn{13}{|l|}{$119.741 \mathrm{~A}$} \\
\hline $\begin{array}{l}5 R-1,39-45 \\
8 R-1,13-18 \\
13 R-3,15-20 \\
14 R-1,40-46\end{array}$ & $\begin{array}{r}33.8 \\
62.6 \\
113.9 \\
120.9\end{array}$ & $\begin{array}{r}260.2 \\
155.0 \\
215.0 \\
94.6\end{array}$ & $\begin{array}{l}4.16 \\
3.21 \\
4.50 \\
4.11\end{array}$ & $\begin{array}{l}-21.3 \\
-24.0 \\
-23.0 \\
-23.5\end{array}$ & $\begin{array}{l}-27.5 \\
-26.3 \\
-26.5 \\
-26.1\end{array}$ & $\begin{array}{l}0.48 \\
0.31 \\
0.33 \\
0.66\end{array}$ & $\begin{array}{r}2 \\
\text { nd } \\
\text { nd } \\
2\end{array}$ & $\begin{array}{r}15 \\
5 \\
10 \\
5\end{array}$ & $\begin{array}{r}10 \\
5 \\
5 \\
5\end{array}$ & $\begin{array}{l}40 \\
75 \\
65 \\
65\end{array}$ & $\begin{array}{l}30 \\
15 \\
20 \\
25\end{array}$ & $\begin{array}{l}5 \\
0 \\
0 \\
0\end{array}$ \\
\hline
\end{tabular}

Note: $\mathrm{nd}=$ not detected

a Based on amorphous kerogen.

belative to PDB

isomers of the extended hopanes that approach thermal equilibrium suggest a maturity well above the present sedimentary setting (Fig. 3). As defined by Mackenzie (1984) the thermal equilibrium values for isomerization reactions for the $22 \mathrm{~S} /(22 \mathrm{~S}+22 \mathrm{R})$ ratios of the $17 \alpha(\mathrm{H}), 21 \beta(\mathrm{H})$ hopanes is 0.6 and for the $20 \mathrm{~S} /(20 \mathrm{~S}+20 \mathrm{R})$ ratios of the $5 \alpha(\mathrm{H}), 14 \alpha(\mathrm{H}), 21 \alpha(\mathrm{H})$ steranes the value is 0.5 . Homologous series of naphthalenes, phenanthrenes, and dibenzothiophenes are also present, which indicate a petroleum related source (Hites et al., 1980). The most abundant aromatic hydrocarbons are the methylphenanthrenes. Monoaromatic and triaromatic sterane distributions are relatively simple. The abundance of $\mathrm{C}_{29}$ steranes, the ratio of triterpanes to steranes $(\sim 3)$, and the presence of diterpanes suggest a predominantly terrestrial source for the extractable organic matter (Huang and Menschein, 1976; Mackenzie, 1984) (Table 5).

Hydrocarbon data and gas chromatograms for samples from Unit V are presented in Tables 3-5 and Figure 4, respectively. Unit V gas chromatograms are dominated by odd $n$-alkanes from $n-\mathrm{C}_{23}$ to $n-\mathrm{C}_{31}$ though trace amounts of other $n$-alkanes from $n-\mathrm{C}_{11}$ to $n-\mathrm{C}_{32}$ are present. The putative source for these long-chained $n$-alkanes is the waxes of vascular plants (Eglinton et al., 1962). CPI values are 3.8 and 4.4 and pristane/phytane ratios are 1.9 to 2.1 . The lower maturity of Unit $\mathrm{V}$ extracts, in comparison to Unit II, is suggested by the abundance of odd $n$ alkanes, low pristane/phytane ratios, and abundant immature aliphatic (i.e., $17 \beta(\mathrm{H}), 21 \beta(\mathrm{H})$ hopanes) biomarkers.

Representative triterpane and sterane fragmentograms are displayed in Figure 5. Both samples from Unit V contain an immature biomarker pattern containing abundant $\mathrm{C}_{29}, \mathrm{C}_{30}$, and $\mathrm{C}_{31}$ $17 \beta(\mathrm{H}), 21 \beta(\mathrm{H})$ and $17 \beta(\mathrm{H}), 21 \alpha(\mathrm{H})$ hopanes; $17 \beta(\mathrm{H})-22,29,30-$ trisnorhopane; extended $17 \alpha(\mathrm{H}), 21 \beta(\mathrm{H})(22 \mathrm{R})$ hopanes; and $5 \alpha(\mathrm{H}), 14 \alpha(\mathrm{H}), 21 \alpha(\mathrm{H})(20 \mathrm{R}) \mathrm{C}_{29}$ steranes. However, mature biomarkers (i.e., $17 \alpha(\mathrm{H}), 21 \beta(\mathrm{H})$ hopanes) are also present in both samples. The aromatic hydrocarbons exhibit relatively simple patterns that are consistent with the low maturity of Unit V sediments.

The composition of organic matter in Units II and V suggests independent thermal histories. Some features of the aliphatic biomarkers are similar, including $\mathrm{T}_{\mathrm{s}} / \mathrm{T}_{\mathrm{m}}$ ratios and the dominance of $\mathrm{C}_{29}$ steranes. The dominance of $\mathrm{C}_{29}$ steranes is generally associated with terrestrial organic material (Huang and Meinschein, 1976), although certain marine organisms may contribute $\mathrm{C}_{29}$ sterols to the sediment (Volkman, 1986). The hydrocarbon patterns confirm the kerogen analyses that suggest that 


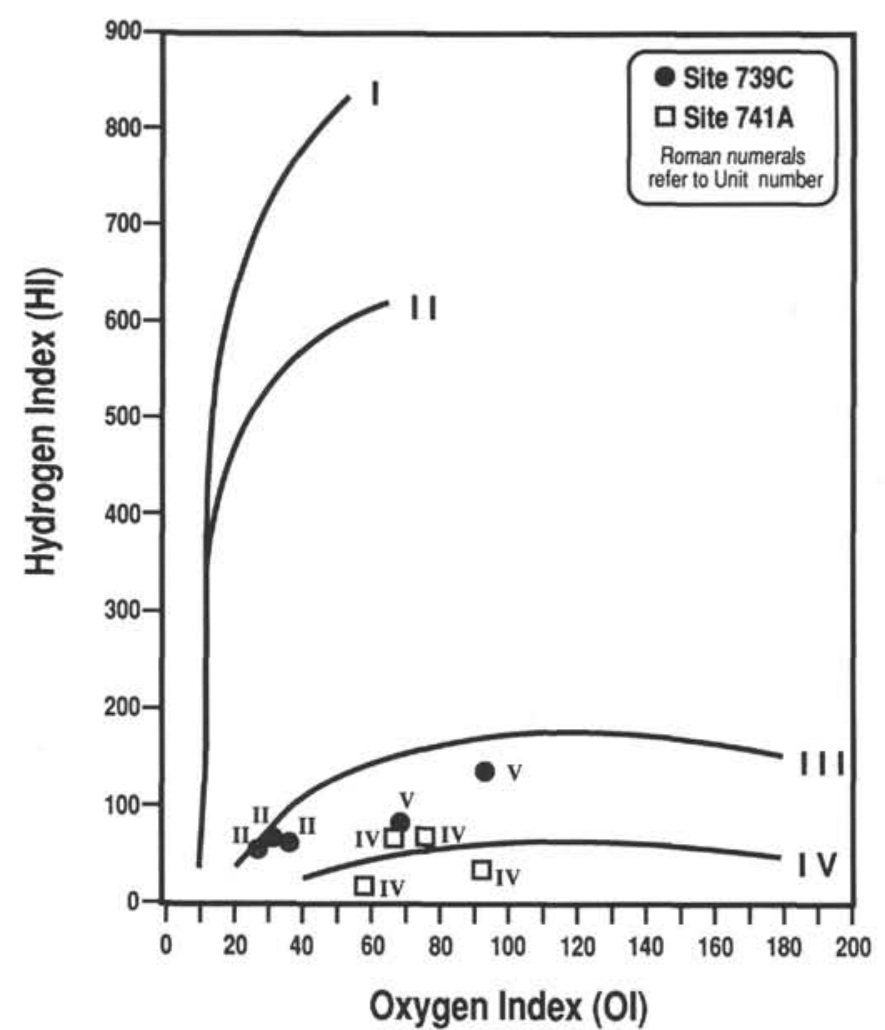

Figure 1. van Krevelen diagram of the elemental composition of kerogens from selected samples, Sites $739 \mathrm{C}$ and 741A.

the majority of the organic matter is of terrestrial origin in both units and that Unit II is more mature than Unit V. Vitrinite reflectance values average $0.7 \%$ and $0.5 \%$ in Units II and V, respectively. This suggests that Unit II is a redeposited, recycled mature section and that the mature extract is indigenous to this reworked material.

\section{Hole 741A-Inner Prydz Bay}

Hole 741A was drilled in the inner part of eastern Prydz Bay in $551 \mathrm{~m}$ of water. The $128.1-\mathrm{m}$ sequence of marine, glacial, glaciomarine, and alluvial sediments ranges in age from Early Cre- taceous to Holocene and is subdivided into four units (Barron, Larsen, et al., 1989; Turner and Padley, this volume). TOC concentrations range from $0.15 \%$ to $6.8 \%(n=20)$ (Barron, Larsen, et al., 1989). The highest values are generally found below 27 mbsf (Unit IV). Samples from Unit IV, 24 to $128 \mathrm{mbsf}$, which contain the highest amounts of organic carbon, were chosen for detailed organic geochemical analysis. Unit IV mainly consists of fine-grained siliciclastic sediment of Early Cretaceous (Albian?) age (Truswell, this volume) deposited on a low-lying, low-relief, alluvial plain (Turner and Padley, this volume). Allochthonous carbonized plant fragments, perhaps remnants of wood, occur commonly in this unit.

\section{Bulk Parameters}

Kerogen analyses of samples from Hole 741A are summarized in Tables 1 and 2 . EOM and organic carbon content vary from 94.6 to $260.2 \mathrm{ppm}$ and $3.21 \%$ to $4.50 \%$, respectively. $\mathrm{T}_{\max }$ values less than $435^{\circ} \mathrm{C}$, HI values of 17 to 69 , OI values of 57 to 92 , PI values less than $0.12, S_{1}$ values less than 0.21 , and $S_{2}$ values ranging from 0.71 to 3.07 suggest organic matter of terrestrial origin that is immature. These characteristics are similar to those of Unit V of Hole 739C except for the higher TOC and $\mathrm{S}_{2}$ values. The higher $S_{2}$ values may result from higher amounts of coaly material in the sediment at Hole 741A (Barron, Larsen, et al., 1989). Visual examination of the kerogen suggests that the majority of the material is vitrinite and inertinite $(70 \%$ to $90 \%)$. When plotted on a van Krevelen diagram, the samples are characterized as highly altered Type IV kerogen (Fig. 1). The carbon isotope composition $\left(\delta^{13} \mathrm{C}\right)$ of the kerogen and EOM range from $-21.3 \%$ to $-24.0 \%$ and $-26.1 \%$ to $-27.5 \%$, respectively. The large differences between $\delta^{13} \mathrm{C}$ values of kerogen and EOM at this site make inferences about their derivation from the same source tenuous.

\section{Extractable Organic Matter}

Quantitative hydrocarbon data and gas chromatograms are presented in data in Tables 3-5 and Figure 6, respectively. Extracts from this site are dominated by long-chain odd-numbered carbon $n$-alkanes and also contain trace amounts of $n$-alkanes with 11 to 32 carbons. CPI values range from 2.2 to $3.2, \mathrm{Pr} / \mathrm{Ph}$ ratios range from 1.2 to 1.6 , and the dominant $n$-alkane is either $\mathrm{n}-\mathrm{C}_{27}$ or $\mathrm{n}-\mathrm{C}_{31}$. These characteristics suggest the presence of immature, terrestrial organic matter. The $n$-alkane and isoprenoid patterns from all of the samples from this site are similar to

Table 3. $n$-alkane and isoprenoid data for selected samples from Leg 119, Holes 739C and 741A.

Core-Section,

Interval (cm)
Depth

(mbsf)
Dominant

$n$-alkane

carbon number
Pristane/Phytane

Ratio
$n-\mathrm{C}_{17} /$ Pristane Carbon Preference Index
Ratio
(CPI)

\section{$119-739 \mathrm{C}$}

16R-3, 28-34

20R-2, 31-37

23R-2, 44-51

47R-1, 71-78

6OR-1, 85-92

119-741A

5R-1, 39-45

8R-1, 13-18

$13 R-3,15-20$

14R-1, 40-46

$\begin{array}{lcc}133.6 & 18 & 3.9 \\ 151.5 & 18 & 3.8 \\ 165.9 & 18 / 19 & 4.3 \\ 386.6 & 25 & 2.1 \\ 473.7 & 25 & 1.9\end{array}$

3.9
3.8
4.3
2.1
1.9

1.6

1.7

1.6

0.8

1.7

1.8

1.7

4.4

3.8

33.8

62.6

113.9

120.9

$\begin{array}{ll}27 & 1.5 \\ 31 & 1.2 \\ 27 & 1.5 \\ 27 & 1.6\end{array}$

3.0

2.9

3.2

2.2 
Table 4. Aliphatic biomarker ratios for selected samples from Leg 119, Holes 739C and 741A.

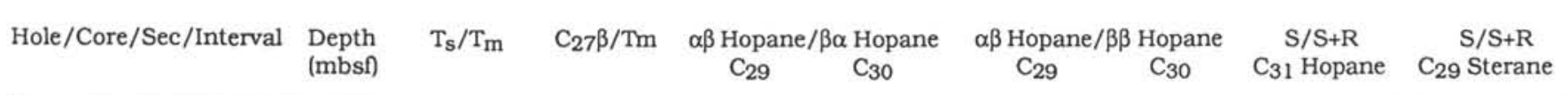

\section{$119-739 \mathrm{C}$}

16R-3, 28-34

20R-2, 31-37

23R-2, 44-51

$47 \mathrm{R}-1,71-78$

60R-1, 85-92

119-741A

5R-1, 39-45

$8 \mathrm{R}-1,13-18$

$13 \mathrm{R}-3,15-20$

$14 \mathrm{R}-1,40-46$

\section{6}

151.5

165.9

386.6

473.7

\subsection{3 \\ 0.13 \\ 0.14 \\ 0.12}

0.13

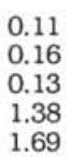

0.11

0.13

1.38

1.69

$\begin{array}{ll}3.62 & 3.05 \\ 2.70 & 2.38 \\ 3.26 & 2.80 \\ 0.81 & 1.50 \\ 0.72 & 1.42\end{array}$

nd
nd
nd
0.82
0.68

nd
nd
nd
1.43
1.18

$\begin{array}{ll}0.62 & 0.44 \\ 0.64 & 0.43 \\ 0.62 & 0.43 \\ 0.30 & 0.16 \\ 0.25 & 0.10\end{array}$

0.44

0.43

0.10
Note: nd = not determined due to one of the compounds not present;
$\mathrm{T}_{\mathrm{S}}=18 \alpha(\mathrm{H})-22,29,30$-trisnorhopane
$\mathrm{T}_{\mathrm{m}}=17 \alpha(\mathrm{H})-22,29,30$-trisnorhopane
$\mathrm{C}_{27} \beta=17 \beta(\mathrm{H})-22,29,30$-trisnorhopane.

Table 5. Quantitative biomarker data for selected samples from Leg 119, Holes 739C and 741A.

\begin{tabular}{|c|c|c|c|c|c|c|c|c|c|}
\hline $\begin{array}{l}\text { Hole } \\
\text { Core-Sec/Interval } \\
\text { (cm) }\end{array}$ & $\begin{array}{l}\text { Depth } \\
\text { (mbsi) }\end{array}$ & $\begin{array}{l}\text { Phenanthrene\& Methyl - } \\
\text { Phenanthrenes } \\
\text { (ppm) }\end{array}$ & $\begin{array}{l}\text { Monoaomatic } \\
\text { Steranes } \\
\text { (ppm) }\end{array}$ & $\begin{array}{l}\text { Triaromatic } \\
\text { Steranes } \\
\text { (ppm) }\end{array}$ & $\begin{array}{l}\text { Total } \\
\text { Diterpanes } \\
\text { (ppm) }\end{array}$ & $\begin{array}{c}\text { Total } \\
\text { Triterpanes } \\
\text { (ppm) }\end{array}$ & $\begin{array}{l}\text { Total } \\
\text { Steranes } \\
\text { (ppm) }\end{array}$ & 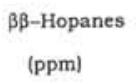 & $\begin{array}{l}\text { Dominant } \\
\text { Triterpane }\end{array}$ \\
\hline \multicolumn{10}{|l|}{$119.739 \mathrm{C}$} \\
\hline $16 \mathrm{R}-3,28-34$ & 133.6 & 17580 & 85 & 236 & 86 & 3060 & 1104 & nd & $\mathrm{C}_{3} \mathrm{O} \alpha \beta$ \\
\hline 20R-2. 31-37 & 151.5 & 15583 & 79 & 293 & 219 & 7046 & 2557 & nd & $\mathrm{C}_{30} \alpha \beta$ \\
\hline $23 R-2,44-51$ & 165.9 & 17048 & 74 & 227 & 77 & 2577 & 986 & nd & $\mathrm{C}_{30} \alpha \beta$ \\
\hline $47 R-1,71-78$ & 386.6 & 3725 & 271 & 182 & 71 & 3836 & 1357 & 1061 & $c_{30} \alpha \beta$ \\
\hline $60 R-1.85-92$ & 473.7 & 388 & 45 & 38 & 75 & 2706 & 1126 & 827 & $C_{27} B$ \\
\hline \multicolumn{10}{|l|}{$119-741 \mathrm{~A}$} \\
\hline $5 R-1,39-45$ & 33.8 & 263 & 76 & 62 & 41 & 7362 & 1174 & 6729 & $C_{27} B$ \\
\hline 8R-1, 13-18 & 62.6 & 253 & 104 & 35 & 33 & 938 & 653 & 428 & $C_{27} \beta$ \\
\hline $13 R-3,15-20$ & 113.9 & 289 & 91 & 58 & 114 & 9069 & 3109 & 7884 & $\mathrm{C}_{31} \beta \beta$ \\
\hline $14 \mathrm{R}-1,40-46$ & 120.9 & 4790 & 176 & 138 & 61 & 1658 & 658 & 737 & $\mathrm{C}_{27} \beta$ \\
\hline
\end{tabular}

Note: $\quad \mathrm{ppm}=$ parts per million, $\mu \mathrm{g} / \mathrm{gm}$ of extract; $\mathrm{C}_{30} \alpha \beta=17(\alpha), 21(\beta)$ Hopane:

$\mathrm{C}_{27} \beta=17 \mathrm{~b}(\mathrm{H})-22,29.30$-trisnorhopane:

$C_{31} \beta \beta=17(\beta), 21(\beta)$ Homohopane:

$\mathrm{C}_{29}(\mathrm{R}) \alpha \alpha \alpha=24$-ethyl-5 $\alpha, 14 \alpha, 17 \alpha$-cholestane (20R).

those in Unit V of Hole 739C, suggesting a similar source of sediment organic matter (i.e., terrestrial), depositional environment, and thermal history.

Representative fragmentograms of the aliphatic biomarkers are displayed in Figure 7. The biomarker patterns from this site are dominated by $\mathrm{C}_{29}, \mathrm{C}_{30}$, and $\mathrm{C}_{31} 17 \beta(\mathrm{H}), 21 \beta(\mathrm{H})$ and $17 \alpha(\mathrm{H})$, $21 \beta(\mathrm{H})$ hopanes; $17 \beta(\mathrm{H})$-22,29,30-trisnorhopane; $17 \alpha(\mathrm{H}), 21 \beta(\mathrm{H})$ (22R) extended hopanes; and $5 \alpha(\mathrm{H}), 14 \alpha(\mathrm{H}), 21 \alpha(\mathrm{H})(20 \mathrm{R}) \mathrm{C}_{29}$ sterane. Triterpane and sterane patterns are similar to the patterns described in Unit V of Hole 739C. Fragmentograms of the aromatic compounds were relatively simple.

\section{CONCLUSIONS}

At Hole $739 \mathrm{C}$ the upper three samples selected for detailed organic geochemical analyses represent a massive diamictite of late Miocene to Quaternary age. The organic matter in this section is mature, based on the aliphatic and aromatic biomarker distributions, $n$-alkane distributions, and vitrinite reflectance. Visual examination and pyrolysis analysis of the kerogen suggest a predominance of terrestrial organic matter. The presence of a mature extract can be attributed to recycling of exposed continental material or upward migration from deeper horizons in the section. The coincidence of mature indicators in bulk organic matter, kerogen, and the extract strongly suggests a recycled origin. This implies that an exposed section of mature organic-rich material was present in Miocene times. The two samples from Unit V are a massive diamictite of middle Eocene to early Oligocene age (Barron, Larsen, et al., 1989). The organic matter in this section is immature based on biomaker, $n$-alkane, and kerogen analysis. Visual and pyrolysis analysis of the kerogen suggests a predominance of terrestrial organic matter that is less thermally altered than that of Unit II. The reversal of thermal maturities, i.e., more mature organic matter overlying less mature sections, may be related to glacial erosion that recycled sediments. 

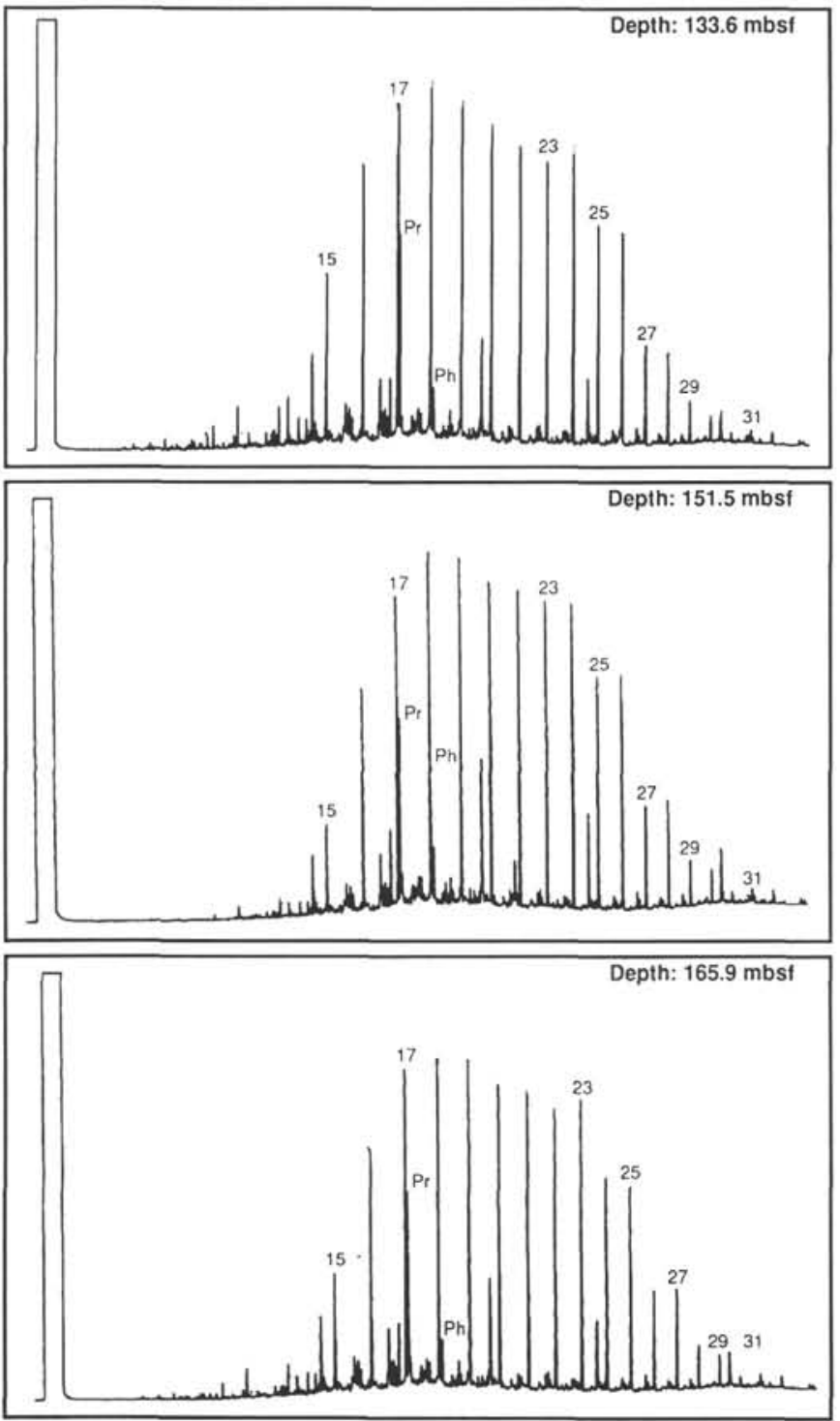

Figure 2. Gas chromatograms (FID) of the extractable organic matter from selected samples of Unit II from Hole 739C. (Numbers indicate $n$ alkanes, $\mathrm{Pr}=$ Pristane, $\mathrm{Ph}=$ Phytane).

Samples selected from Hole 741A, Lower Cretaceous siliciclastic (Barron, Larsen, et al., 1989), are similar to samples from Unit V of Hole 739C. Based on aliphatic and aromatic biomarker, $n$-alkane distributions, and kerogen analysis, the organic matter from the Cretaceous sediments is immature. Visual examination and pyrolysis analysis of the kerogen suggests predominantly terrestrial organic matter that is relatively immature. The similarities between Hole 739C Unit V and Hole 741A suggest that the source of the organic matter in the glacial sediments in Unit V at Hole 739C could be Cretaceous in age and similar to sediments sampled at Hole 741A in Prydz Bay.

\section{REFERENCES}

Barker, C., 1979. Organic Geochemistry in Petroleum Exploration: AAPG Continuing Education Course Note Series, 10.

Barron, J., Larsen, B., et al., 1989. Proc. ODP, Init. Repts., 119: College Station, TX (Ocean Drilling Program).

Dow, W. G., 1977. Kerogen studies and geological interpretations. J. Geochem. Explor., 7:79-99.
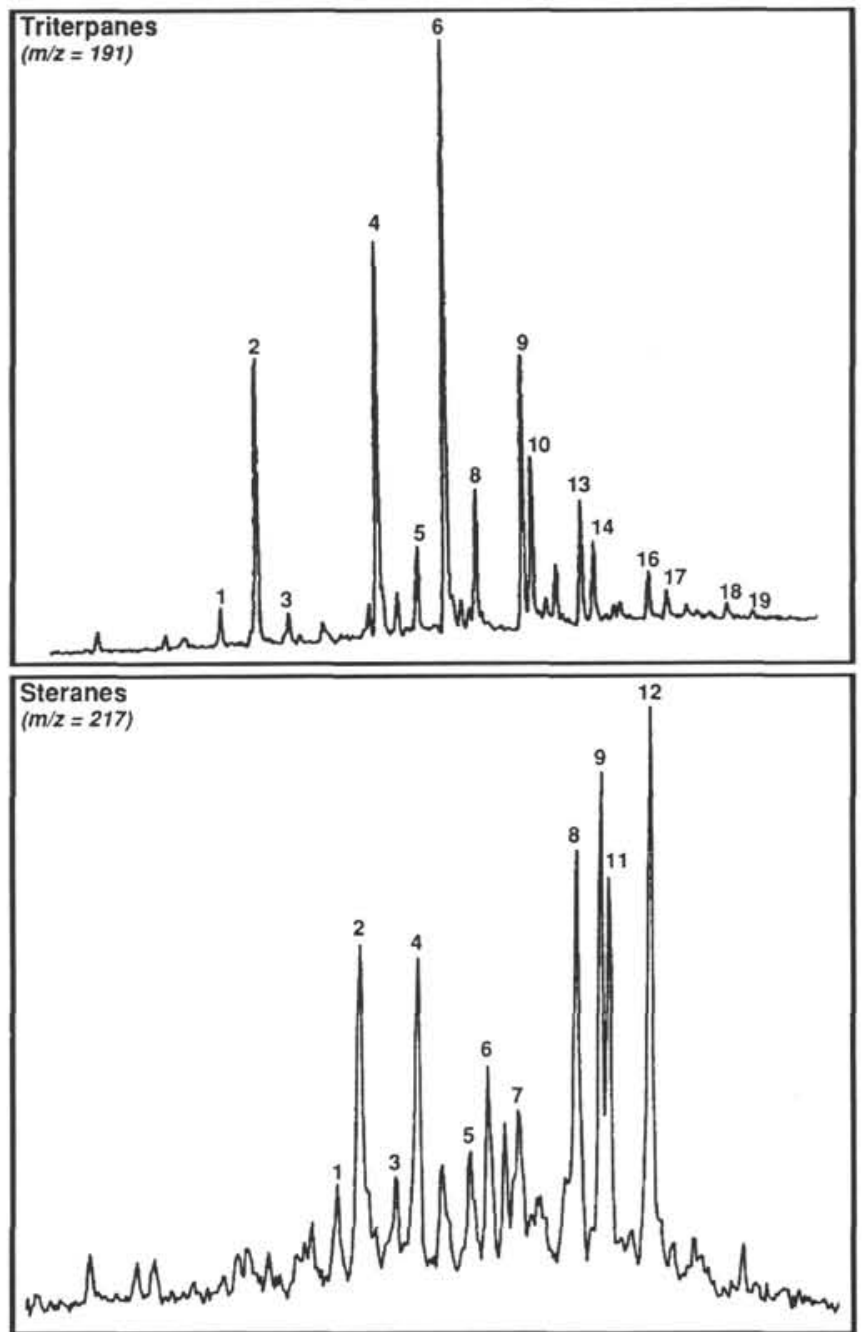

Figure 3. Mass fragmentograms of $\mathrm{m} / \mathrm{z} 191$ (triterpanes) and $\mathrm{m} / \mathrm{z}=$ 217 (steranes) of the aliphatic fraction of selected samples, Unit II, Hole 739C. Compound identification is listed in the Appendix.

Eglinton, G., Gonzales, A. G., Hamilton, R. J., and Raphael, R. A., 1962. Hydrocarbon constituents of the wax coatings of plant leaves: a taxonomic survey. Phytochemistry, 1:89-102.

Farrington, J. W., and Meyers, P. A., 1975. Hydrocarbons in the marine environment. In Eglinton, G. (Ed.), Environmental Chemistry (Vol. 1): London (Chemical Society), 109-136.

Farrington, J. W., Teal, J. M., Quinn, J. G., Wade, T. L., and Burns, K., 1973. Intercalibration of analyses of recently biosynthesized hydrocarbons and petroleum hydrocarbons in marine lipids. Bull. Environ. Contam. Toxicol., 10:129-146.

Hites, R. A., LaFlamme, R. E., Windsor, J. G., Jr., Farrington, J. W., and Deuser, W. G., 1980. Polycyclic aromatic hydrocarbons in an anoxic sediment core from the Pettaquamscutt River (Rhode Island, USA), Geochim. Cosmochim. Acta, 44:873-878.

Huang, W.-Y., and Meinschein, W. G., 1979. Sterols as ecological indicators. Geochim. Cosmochim. Acta, 43:739-745.

Killops, S. D., and Readman, J. W., 1985. HPLC fractionation and GC-MS determination of aromatic hydrocarbons for oils and sediments. Org. Chem., 8:247-257.

Mackenzie, A. S., 1984. Application of biological markers in petroleum geochemistry. In Brooks, J., and Welte, D. (Eds.), Advances in Petroleum Geochemistry (Vol. 1): London (Academic Press), 115-214.

Peters, K. E., 1986. Guidelines for evaluating petroleum source rock using programmed pyrolysis. AAPG Bull., 70:318-329. 
Philp, R. P., 1985. Biological markers in fossil fuel production. Mass Spectrom. Rev., 4:21-28.

Schoell, M., 1982. Application of isotope analysis to petroleum and natural gas research. Spectra, 8:32-41.

Tegelaar, E. W., de Leeuw, J. W., Derenne, S., and Largeau, C., 1989. A reappraisal of kerogen formation. Geochim. Cosmochim. Acta, 53: 3103-3106.

Tissot, B. P., and Welte, D. H., 1978. Petroleum Formation and Occurrence: Heidelberg (Springer-Verlag).

Volkman, J. K., 1986. A review of sterol markers for marine and terrigenous organic matter. Org. Geochem., 9:83-99.

Date of initial receipt: 14 December 1989

Date of acceptance: 24 July 1990

Ms 119B-176
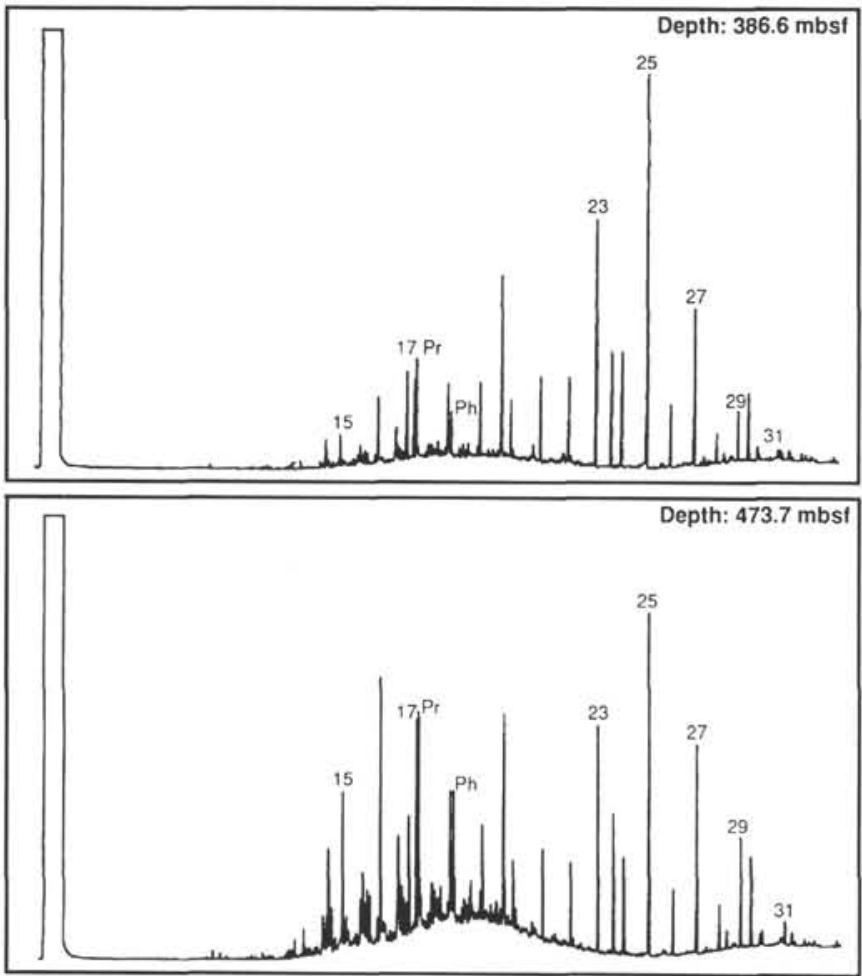

Figure 4. Gas chromatograms (FID) of the extractable organic matter from selected samples of Unit V, Hole 739C. (Numbers indicate $n$-alkanes, $\mathrm{Pr}=$ Pristane, $\mathrm{Ph}=$ Phytane).
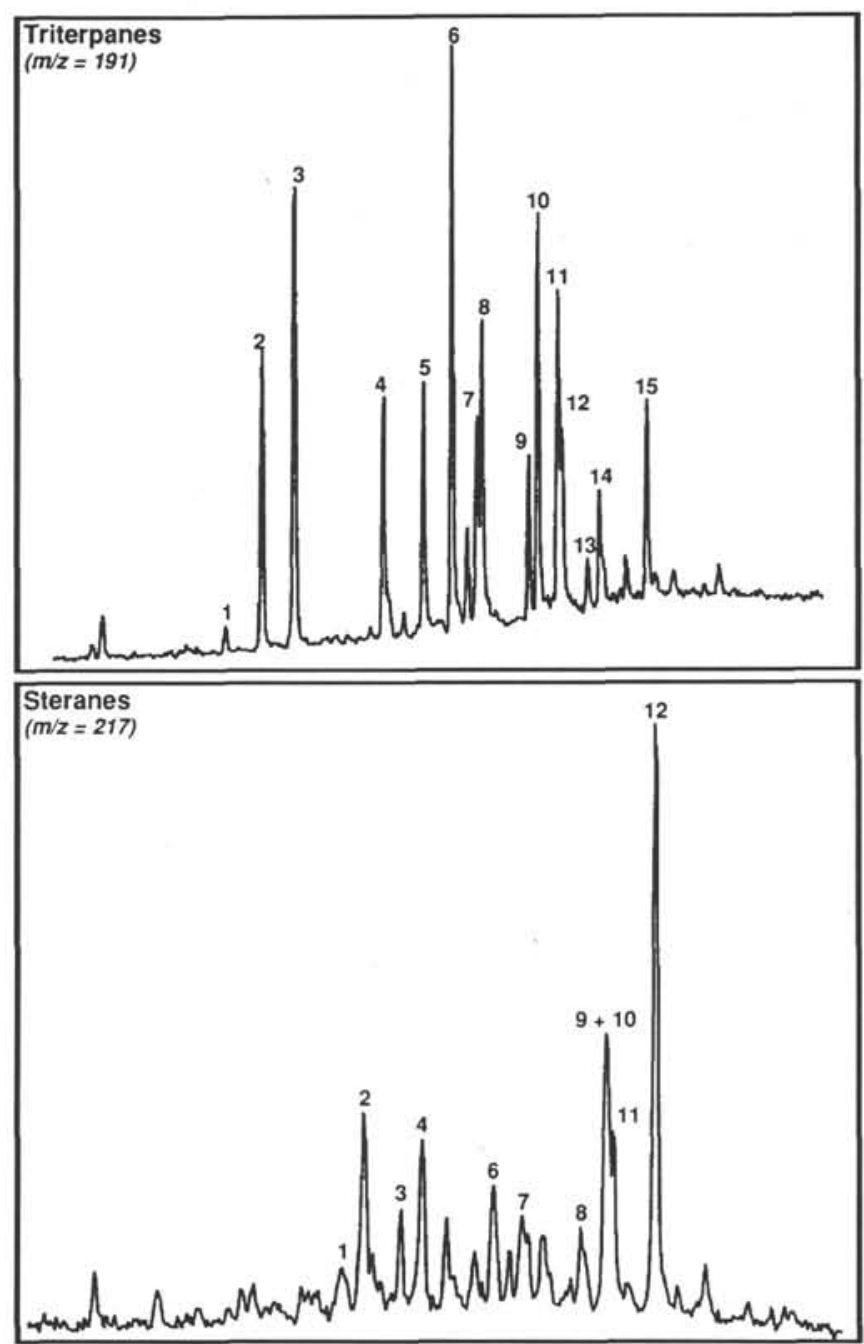

Figure 5. Mass fragmentograms of $\mathrm{m} / \mathrm{z} 191$ (triterpanes) and $\mathrm{m} / \mathrm{z}=$ 217 (steranes) of the aliphatic fraction of selected samples from Unit V, Hole 739C. Compound identification is listed in the Appendix. 
A
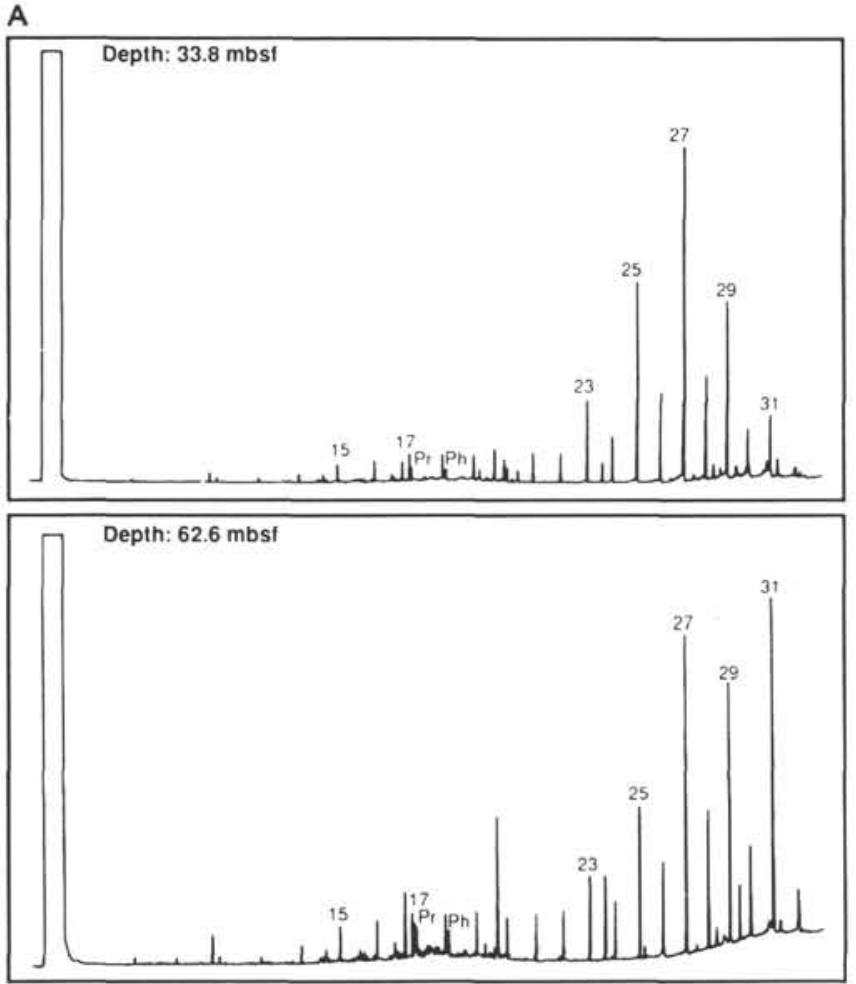
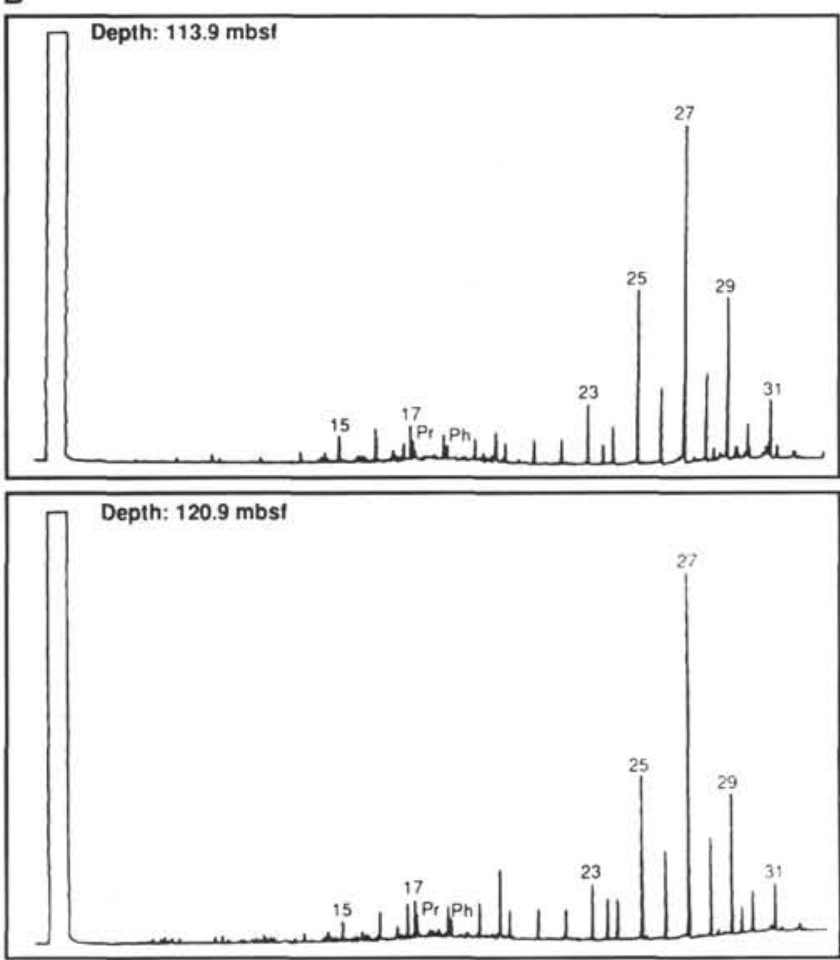

Figure 6. Gas chromatograms (FID) of the extractable organic matter from the selected samples of Hole 741A. (Numbers indicate $n$-alkanes, Pr $=$ Pristane, $\mathrm{Ph}=$ Phytane). 

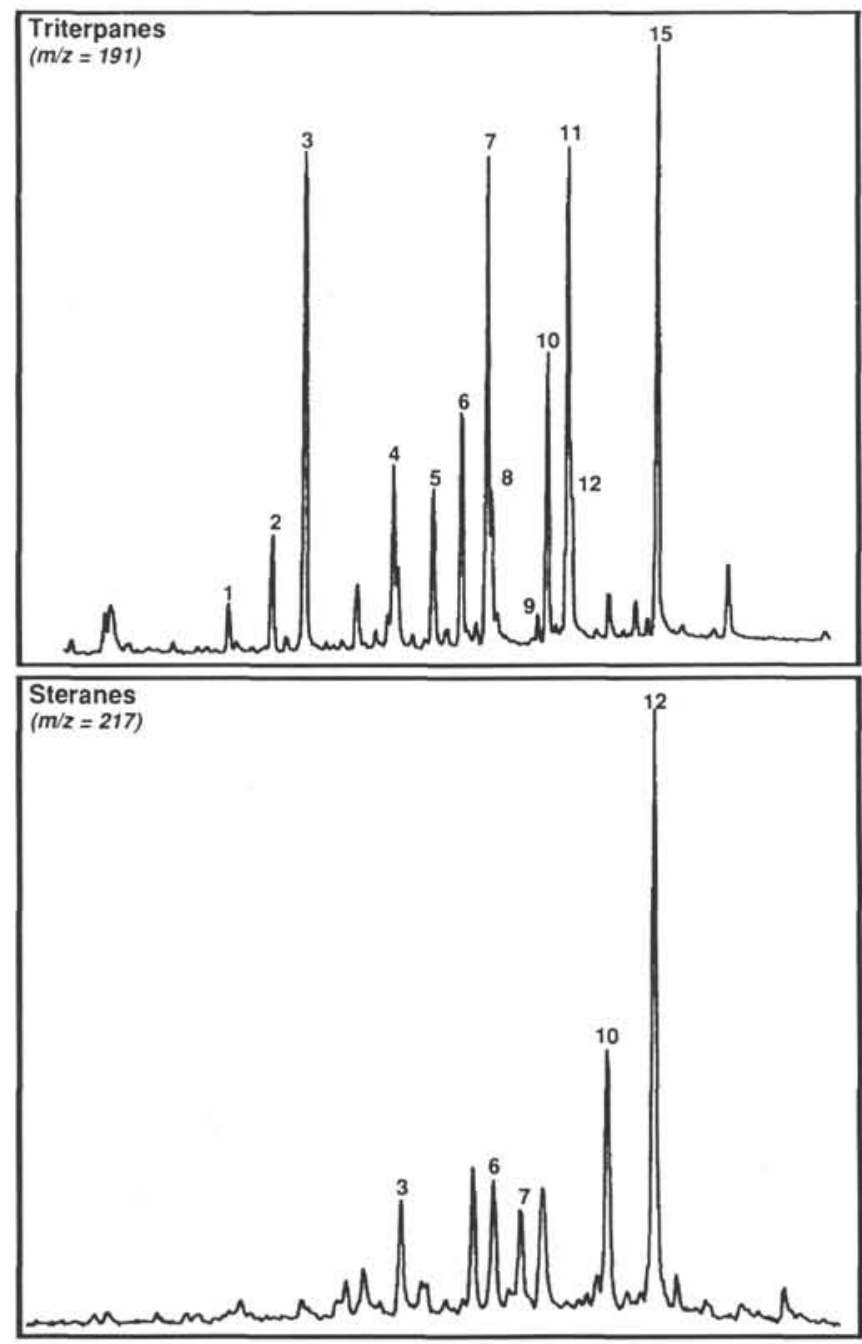

Figure 7. Mass fragmentograms of $\mathrm{m} / \mathrm{z} 191$ (triterpanes) and $\mathrm{m} / \mathrm{z}=$ 217 (steranes) of the aliphatic fraction of selected samples from Hole 741A. Compound identification is listed in the Appendix. 
APPENDIX

\begin{tabular}{llll} 
Peak no. & Formula & Molecular weight & \multicolumn{1}{c}{ Identification } \\
\hline \hline & & 370 & $18 \alpha(\mathrm{H})-22,29,30$-trisnomeohopane $\left(\mathrm{T}_{\mathrm{S}}\right)$ \\
1 & $\mathrm{C}_{27} \mathrm{H}_{46}$ & 370 & $17 \alpha(\mathrm{H})-22,29,30$-trisnorhopane $\left(\mathrm{T}_{\mathrm{m}}\right)$ \\
2 & $\mathrm{C}_{27} \mathrm{H}_{46}$ & 370 & $17 \beta(\mathrm{H})-22,29,30$-trisnorhopane \\
4 & $\mathrm{C}_{27} \mathrm{H}_{46}$ & 398 & $17 \alpha(\mathrm{H}), 21 \beta(\mathrm{H})-30$-norhopane \\
5 & $\mathrm{C}_{29} \mathrm{H}_{50}$ & 398 & $17 \beta(\mathrm{H}), 21 \alpha(\mathrm{H})$-normoretane \\
6 & $\mathrm{C}_{29} \mathrm{H}_{50}$ & 412 & $17 \alpha(\mathrm{H}), 21 \beta(\mathrm{H})$-hopane \\
7 & $\mathrm{C}_{30} \mathrm{H}_{52}$ & 398 & $17 \beta(\mathrm{H}), 21 \beta(\mathrm{H})$-norhopane \\
8 & $\mathrm{C}_{29} \mathrm{H}_{50}$ & 412 & $17 \beta(\mathrm{H}), 21 \alpha(\mathrm{H})$-moretane \\
9 & $\mathrm{C}_{30} \mathrm{H}_{52}$ & 426 & $22 \mathrm{~S}-17 \alpha(\mathrm{H}), 21 \beta(\mathrm{H})$-30-homohopane \\
10 & $\mathrm{C}_{31} \mathrm{H}_{54}$ & 426 & $22 \mathrm{R}-17 \alpha(\mathrm{H}), 21 \beta(\mathrm{H})-30$-homohopane \\
11 & $\mathrm{C}_{31} \mathrm{H}_{54}$ & 412 & $17 \beta(\mathrm{H}), 21 \beta(\mathrm{H})$-hopane \\
12 & $\mathrm{C}_{30} \mathrm{H}_{52}$ & 426 & $17 \beta(\mathrm{H})-21 \alpha(\mathrm{H})$-homomoretane \\
13 & $\mathrm{C}_{31} \mathrm{H}_{54}$ & 440 & $22 \mathrm{~S}-17 \alpha(\mathrm{H}), 21 \beta(\mathrm{H})-30,31$-bishomohopane \\
14 & $\mathrm{C}_{32} \mathrm{H}_{56}$ & 440 & $22 \mathrm{R}-17 \alpha(\mathrm{H}), 21 \beta(\mathrm{H})-30,31$-bishomohopane \\
15 & $\mathrm{C}_{32} \mathrm{H}_{56}$ & 426 & $17 \beta(\mathrm{H}), 21 \beta(\mathrm{H})$-homohopane \\
\hline
\end{tabular}

Tentative identifications of sterane compounds $(\mathrm{m} / \mathrm{z}=217)$

Peak no. Formula Molecular weight Identification

\begin{tabular}{|c|c|c|c|}
\hline \multirow[t]{2}{*}{1} & $\mathrm{C}_{28} \mathrm{H}_{50}$ & 386 & 24-methyl-13 $\alpha, 17 \beta$-diacholestane (20S) \\
\hline & $\mathrm{C}_{27} \mathrm{H}_{48}$ & 372 & $5 \alpha, 14 \alpha, 17 \alpha$-cholestane (20S) \\
\hline \multirow[t]{2}{*}{2} & $\mathrm{C}_{29} \mathrm{H}_{52}$ & 400 & 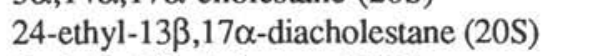 \\
\hline & $\mathrm{C}_{27} \mathrm{H}_{48}$ & 372 & $5 \alpha-14 \beta, 17 \beta$-cholestane (20R) \\
\hline 3 & $\mathrm{C}_{27} \mathrm{H}_{48}$ & 372 & $5 \alpha, 14 \alpha, 17 \alpha$-cholestane (20R) \\
\hline 4 & $\mathrm{C}_{29} \mathrm{H}_{52}$ & 400 & 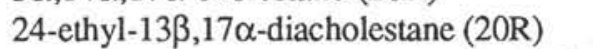 \\
\hline 5 & $\mathrm{C}_{28} \mathrm{H}_{50}$ & 386 & 24-methyl-5 $\alpha, 14 \alpha, 17 \alpha$-cholestane (20S) \\
\hline 6 & $\mathrm{C}_{28} \mathrm{H}_{50}$ & 400 & 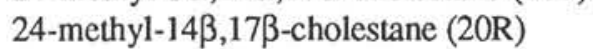 \\
\hline 6 & $\mathrm{C}_{29} \mathrm{H}_{50}$ & 386 & 24-ethyl-13a,17ß-diacholestane (20R) \\
\hline 7 & $\mathrm{C}_{28} \mathrm{H}_{50}$ & 386 & 24 -methyl-5 $\alpha, 14 \alpha, 17 \alpha$-cholestane (20R) \\
\hline 8 & $\mathrm{C}_{29} \mathrm{H}_{52}$ & 400 & 24-ethyl-5 $\alpha, 14 \alpha, 17 \alpha$-cholestane (20S) \\
\hline 9 & $\mathrm{C}_{29} \mathrm{H}_{52}$ & 400 & 24 -ethyl-5 $\alpha, 14 \beta, 17 \beta$-cholestane (20R) \\
\hline 10 & $\mathrm{C}_{29} \mathrm{H}_{52}$ & 400 & 24-ethyl-5 $\beta, 14 \alpha, 17 \alpha$-cholestane \\
\hline 11 & $\mathrm{C}_{29} \mathrm{H}_{52}$ & 400 & 24 -ethyl $5 \alpha, 14 \beta, 17 \beta$-cholestane (20S) \\
\hline 12 & $\mathrm{C}_{29} \mathrm{H}_{52}$ & 400 & 24-ethyl-5 $\alpha, 14 \alpha, 17 \alpha$-cholestane (20R) \\
\hline
\end{tabular}

